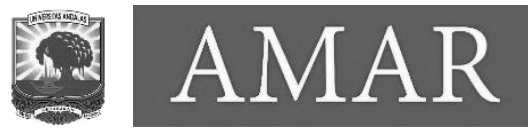

AMAR (Andalas Management Review)

Vol. 3, No. 1 (2019) page 1-17

The Management Institute, Faculty of Economics, Andalas University

ISSN (Print) 2476-9282 | ISSN (Online) 2548-155X

\title{
Linking Perceived Educational Support to Entrepreneur Intention: The Mediating Effect of Self-Confidence
}

\author{
Purbo Jadmiko, Elfitra Azliyanti, Tyara Dwi Putri \\ aManagement Department, Faculty of Economics, Bung Hatta University, \\ purbojadmiko@bunghatta.ac.id
}

\begin{abstract}
Applying the conceptual framework of value-attitude-behavior relationship, this study investigates selfconfidence as mediating effect on the relationship between perceived educational supporton entrepreneur intention. Using linier regression analysis, we investigate the role of self-confidence, perceived educational support on entrepreneur intention. In this paper, we used 160 students of economic faculty at Bung Hatta University. These results suggest that perceived educational support and self-confidence have positive effects on entrepreneur intention, and perceived educational support has positive effect on entrepreneur intention. This result shows self-confidence play an important role as a mediating variable on the relationship between perceived educational support on entrepreneur intention.
\end{abstract}

Keyword: perceived educational support, self-confidence, entrepreneur intention

\section{INTRODUCTION}

Unemployment is an important issues which faced by every country, particularly in developing countries. Unemployment is cause by various aspects, particularly educational background difference. We refer it as an educated unemployed. Indonesia have a lot of university that produces more scholars who will go to the working world soon to implement their knowledge that learned in college. However, job termination ("Termination of never ending Employment") also become a critical problem in Indonesia. Blau and Duncan (1967) study results in the United States Mark Blaug (1974) in the UK and Cummings (1980) show majority graduates in Indonesia do not ready to work.

In November 2016, Badan Pusat Statistika (BPS) shows only 12.24 percent of graduates who get the job. It is equivalent to 14.57 million from 118.41 million workers in Indonesia, while 11.19 percent unemployment from graduates or equal 787 thousands from 7.03 million people 
who do not have a job. The Ministry of Research, Technology and Higher Education noted there are 3,221 universities in Indonesia currently and there are 1,020 high religious figures. In addition, every year there are 750 thousand high school graduates from various levels. This evidence exhibits an ironic picture because a high level of education does not guarantee a person to get a job.

Indonesian government and private sector have been trying to produce more entrepreneurs from younger generation by organizing competitions and providing entrepreneurial grants through many programs, such as Student Creativity Entrepreneurship Program, Entrepreneurship Student Program, independent Entrepreneurial Student and others. It's an opportunity for students to gain a capital, which can be used as an initial capital to run the business. Moreover, entrepreneurship course plays an important role in increasing entrepreneurial intention that provides practical experience from business actors in SMEs to students.

A successful entrepreneur has some characteristics such as a strong motivation, courage in taking risks, perseverance and tenacity in running the business, so it can make a strong foundation for an entrepreneur to be consist and not easily discouraged. This situation will be realized if the entrepreneurial spirit can be trained from an early age and family role as a main educator for their children. Early age is a very important period in developing children's life for the future. At this time, the role of parents is needed in shaping their lifestyle by emphasizing the values of religion, motivate to study hard, and educate them with entrepreneurial spirit so that they will realize the importance of religious, personality and independent in financial terms. This is because success can be determined by education, experience and learning from an early age.

Entrepreneurship education has been considered as an important factor to build and develop passion and behavior entrepreneurships among the younger generation (Kourilsky and Walstad, 1998), so that it is necessary to have an understanding on how to develop students potential to become a young entrepreneurs since they have been school. Several studies suggested that the student entrepreneurship intention is a source to develop the future entrepreneurs (Gorman et al., 1997; Kourilsky and Walstad, 1998). Their attitudes and knowledge of entrepreneurship will shape their behavior to start a business. 
Zimmerer (2002), said university plays a critical factor in developing a growth of entrepreneurship through education of entrepreneurship. The university is responsible in educating and improving the students entrepreneurship skills and motivate them to choose entrepreneurship as career. Based on empirical evidence, university should implement a concrete entrepreneurial learning to complete students with a meaningful knowledge that can encourage their spirit for entrepreneurship (John 2003, Wu \&Wu, 2008). In addition, selfconfidence also play an important role in encouraging students intention, because with a strong confidence students willing to take a risk becoming entrepreneur. A person who has the selfconfidence characteristics as an entrepreneur can be seen from their attitudes and beliefs to start, perform and complete the task. Therefore, people who have a confidence always have a value of confidence, optimism, individuality, and dependence on something. According to Suryana (2006: 39) confidence is internal, very relative, dynamic, and determining by the ability to start and complete a job. The confident person has the ability to complete the work systematically, planned, effectively and efficiently. Confidence is always demonstrated by calm, perseverance, excitement, and steadiness in doing the work. Confidence is also determined by independence and self-ability.

A person with high self-confidence relatively is more able to face and solve problems without expecting help from others. Self-confidence affects a person's mental attitude directly and indirectly. Ideas, initiative, creativity, courage, perseverance, the spirit of work and so on are influenced by level of self confidence that associated with knowledge, skills and vigilance. Confidence is a strong foundation for improving individual work and ideas. Alma (2013: 53) argues self-confidence is the most important factor that entrepreneur should have. A person will have a high self-esteem if he does not doubt with the other opinioins. The characteristic of individual maturity such as independent, responsibilty, objective and critical, stable emotions, not easily offended, a high level of social life, willing to help and religious. The indicators of self-confidence are: (1) self-confidence; (2) independent; (3) optimistic; (4) perseverance; (5) the spirit of hard work.

\subsection{Entrepreneurship}

Suryana (2000: 7) summarizes several notion about the entrepreneurship. First, entrepreneurship is a value embodied in the behavior that is used as the basis of resources, 
driving forces, goals, strategies, tips, processes and business results (Sanusi in Suryana, 1994). Second, entrepreneurship is an ability to create a new and different (Drucker in Suryana, 1995). Third, entrepreneurship is a process of applying creativity and innovation in solving problems and finding opportunities to improve life (Zimmerer in Suryana, 2000). Fifth, entrepreneurship is a process of doing something new (creative) and something different (innovation) that is useful to give value more (Suryana, 2000: 8). Finally, Suryana (2000:8) exhibits that a entrepreneurship is an effort to create added value by combining resources through new and different ways to win the competition. The added value is created by developing technologies, discovering new knowledge, finding a better approach to enhance existing goods and services, and to deliver customer satisfaction. (Suryana, 2000: 8). We argue an entrepreneur should have a strong vision, predict and anticipate for uncertainty future and problem solving skills. It was supported by Alma (2001: 39) who claimed an entrepreneur should several qualities such as confidence, duty-oriented and result, risk taking, leadership, originality, oriented forward and creativity.

\subsection{Entrepreneurial Intention}

Human action was derived by internal and external stimulations, it can't be without individual intention. In general, intention is a tendency towards something (Muhadjir, 1992: 72). Intention are a set of mental condition consisting of feelings, hopes, positions, prejudices on a tendency that lead individuals toward a particular choice (Mapiere 1982: 60), whereas Martensi (1988: 6) argue intention affects the process and results of learning individual because if they learn something with high intention they can produce a better result. In addition, intention is "a feeling interested or related to something or activity without any order" (Tarmudji, 1991: 59).

According to Tarmudji (1996), entrepreneurship is a strong willingness to do useful activities. Moreover, entrepreneurship also can be interpreted as an ability to discover business opportunities, gather resources and take an appropriate action to ensure business success (Merediht, 2002). Entrepreneurship intention is a psychological phenomenon which emphasized a passions and benefits to become an entrepreneur.

\subsection{Factors Affecting Entrepreneurship Intention}


Sarwoko (2011) claimed there are several environmental factors that affect individual intention such as family, school and community environments. However, accepts a relationship between individual with something outside themself so that the intention is not stable in some circumstances, intention can vary, depending on the factors that influence it. Intention is related to the attention, further several factors such as authentic, mood or feeling, environmental circumstances, stimulants and willingness. Kram (1983) and Shapero and Sokol (1982) found education and training affect people's perceptions about entrepreneurial intention by providing an opportunity to simulate start-up and observing a role model. Sagie and Elizur (1999) quotes Hisrich (2002) said: "entrepreneurship courses are taken, increasing the interest in starting a new venture ..."A strong education base is almost a prerequisite for entrepreneurial activity and company formation in an area ". Therefore, entrepreneurship education should be designed in particular ways to encourage student entrepreneurship intention.

The influence from several factors such as family, education and work experience are become an important factor to develop entrepreneurial intention (Krueger \& Brazeal, 1994; Segal, Borgia, \& Schoenfeld, 2002 in Farzier \& Niehm, 2008). Parents have a strong impact on the individual intention to become entrepreneurial, research shows entrepreneurs usually have parents who are an entrepreneur too (Peterman \& Kennedy, 2003 in Farzier \& Niehm, 2008). Education and work experience can influence individual to choice their carreer by introducing new ideas, building a necessary skills and providing access to role models (Nabi, Holden \& Walmsley, 2006).

\subsection{Perceived Educational Support}

Zimmerer (2002), said university play a critical factor in developing a growth of entrepreneurship through education of entrepreneurship. Traditional entrepreneurship education focuses on the business plans, how to get financing, business development and small business management as well as entrepreneurial principles. However, if students know content of traditional entrepreneurship education they not necessarily want to become a successful entrepreneur (Hisrich and Peters, 2002).

We argue entrepreneurship courses should be designed to be able to develop entrepreneurial characteristics specifically, such as creativity, decision-making, leadership, 
social networking, time management, teamwork and seen. Therefore, it is necessary to change the entrepreneurship education system that focused on orientation functional control such as financial, marketing, human resources and operation (Meyer in Bell, 2008) to develop entrepreneurship spirit for students. The purpose of entrepreneurial learning on how to entrepreneurial transform the spirit, attitudes and behaviors of entrepreneur groups that can be the ingredients to enter other entrepreneurial environments such as academic, government and social entrepreneur. This course is designed on orientation to produce an entrepreneur specially who becomes the owner of business or an entrepreneur candidate who able to establish, own and manage the company and enter the market professionally. Therefore the pattern of learning should be systemic, which includes theory, practice and implementation (Adhitama, 2014).

Based on social cognitive career theory, career intention are shaped by memorable experiences directly that provide an opportunity for individuals to practice, get a feedback and develop skills that improve personal efficacy and the best result (Lent, Brown and Hackett in Farzier and Niehm, 2008 ). Kram (1983) and Shapero and Sokol (1982) found education and training affect people's perceptions about entrepreneurial intention by providing an opportunity to simulate start-up and observing a role model. It means the entrepreneurship education is not enough to be held only in the classroom lead by lecturer, but should provide an opportunity for students to feel directly how difficult it is to start a business, run it, and also get a chance to observe a role model, the entrepreneur who has run his business in apprenticeship forms.

\subsection{Self Confidence}

Suryana (2013: 23) said self-confidence is the way we thinking of ourselves. Selfconfidence is an attitude that can be grown from being self-sufficient, ability to self-control and did not controled by others and how we value ourselves as others judge us, so that we can face any situation. According to Schunk (2012: 202) confidence refers to one's perceptions of his ability to produce an action. Meanwhile Lauster (2003) argued self-confidence is not an inherited trait but derived from life experience, and can be taught and instilled through education, so that individual need a certain efforts to shape and increase confidence. 
Confidence is shaped and developed through the learning process when individual interact with the environment. Lauster (2003) said the characteristics of people who have the confidence that is: (1) Believe in his own ability. Trust or confidence in the abilities that exist in a person. (2) Decision making independently. Can act in decision making against self that is done independently or without the involvement of others and able to believe in action has been taken. (3) Have a positive sense of yourself. If individual has the confidence and they failed usually they can still review the positive side of the failure. (4) Brave to express opinions. The existence of an attitude to be able in expressing something in the self without any coercion or sense that can inhibit the disclosure.

Suryana's study (2006), determine how the entrepreneurship intention of Electrical Engineering Students from Semarang State University. The study finds entrepreneurship intention of Electrical Engineering Students from Semarang State University is $81.25 \%$. It can be argued Electrical Engineering Students from Semarang State University has a high entrepreneurship intention.

Annas (2009), conducted a study at students of the faculty of Economics faculty of Andalas University, which tries to analyze internal and external factors that improve student entrepreneurship spirit. The study finds internal and external factors, and entrepreneurial spirit have a significant impact to improve entrepreneurship spirit.

Tjahjono \& Ardi's study (2008) focused how student of Muhammadiyah Yogyakarta University to become an entrepreneur. The study finds attitude, subjective norms and control of behavior perceived have a significant effect toward students intention to become an entrepreneur simultaneously.

Adhitama's study, (2014) focused on factors influence entrepreneurship intention (case study on student of Faculty of Economics and Business Undip, Semarang). This study aims to determine the effect of income expectations, family environment, and education on entrepreneurial intention on students at the Faculty of Economics and Business, UNDIP. This research was conducted by quantitative method and using a questionner to collect data. in this research, we used students of Faculty of Economics and Business, Undip as a sampel, and using multiple regression analysis to data analyze. The results showed that: (1) There is a positive effect of income expectations on entrepreneur intention. It's means that higher income will 
increase the entrepreneurship intention. (2) There is a positive influence of family environment on entrepreneurship intention. It's means if there is a supporting family environment, it will increase entrepreneurship intention. (3) There is a positive effect of entrepreneurship education on entrepreneurship intention. It means the better entrepreneurship education will increase entrepreneurship intention.

Bernstein and Carayannis's study (2012), fund a positive relationship between confidence with career intention as an entrepreneurship in the majors of entrepreneurship. When students have a strong confidence in entrepreneurship then he takes the risks and have a better estimate and sense of optimistic to face any problems as an entrepreneurship.

Supriyatno (2017) also find a significant positive influence of self-confidence on entrepreneurship intention from students of Economic Education Studies Program STKIP PGRI Ngawi. This result shows that the students of Economic Education Study Program STKIP PGRI Ngawi have high self-confidence towards business intention. Moreover, students with a higher self-confidence will have a higher entrepreneurship intention too, because starting a business requires a belief in their ability to bring the business success, so that it will motivate them to start a business.

\subsection{Research Hypothesis}

\section{The influence of educational support on entrepreneur intention}

Entrepreneurship education has been considered as an important factor to build and develop passion and behavior entrepreneurships among the younger generation (Kourilsky and Walstad, 1998). Education, knowledge that can be during college is capital the basis used for the self-employed, as well as the skills acquired during the lecture, especially in the course of practice (Adi, 2002). According to Zimmerer (2002), university play a critical factor in developing a growth of entrepreneurship in a country through a research on entrepreneurship education. Previous Scholars believe students entrepreneurship intention is a source for a new entrepreneur in the future (Gorman et al., 1997; Kourilsky and Walstad, 1998). Their knowledge of entrepreneurship tends to encourage them to start a business in the future.

External factors such as a educational support from university is also influence entrepreneurship intention (Siregar, 2009). This argument is supported by Adhitama's study 
(2014) which also found a positive influence of entrepreneurship education on entrepreneurship intention. It means a better entrepreneurship education will increase entrepreneurship intention.

\section{$H_{1}$ : Perceived educational support has a positive effect on entrepreneur intention}

The influence of perceived educational support on self confidence

The child character is built through several things that they heard, seen and perceived. Hearing and sight is the entrance of the lesson before entering to forge his conscience. Through all the senses that human beings have, there will be strong learning related to what is received by the senses. If the children are familiar with the aspects of entrepreneurship since childhood, then they will have a strong character later. Moreover, if the school provides a subject in entrepreneurship, it will raise student entrepreneurship intention (Martaja, 2009).

$\mathrm{H}_{2}$ : Perceived educational support has a positive effect on self confidence

The influence of self-confidence mediated relationship perceived entrepreneur intention to entrepreneur intention

Kaijun et al. (2015) cliamed entrepreneurship education is able to mediate the relationship between trust and student entrepreneurship intentions in China. Sarwoko (2011) add a support from friends, family and people who are considered important have a positive effect on entrepreneurship intentions. In General, the influence of self confidence toward student entrepreneurship intentions is dependent on the parents or people who are considered to contribute to their life in the future relatively. The results show an entrepreneurship education plays an important role in mediating the influence of subjective norms on entrepreneurial intentions, it means self-confidence has an positive effect on entrepreneurial intentions through entrepreneurship education.

$H_{3}$ : Self confidence mediates the relationship between perceived educational support and entrepreneur intention 


\subsection{Research Model}

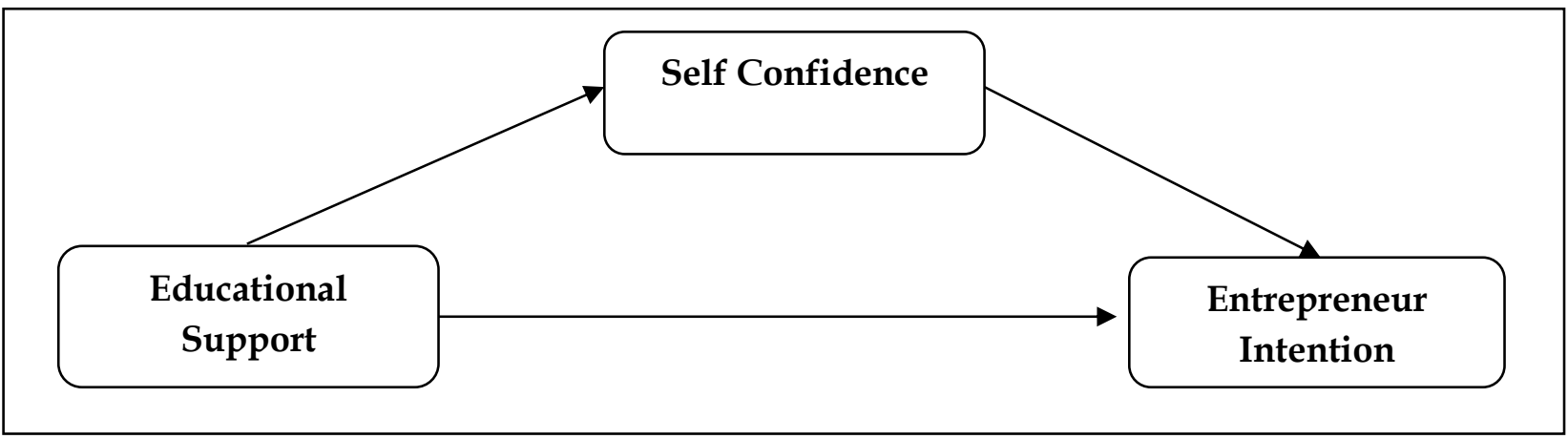

Figure 1. Research Model

\section{RESEARCH METHOD}

This research used a quantitative approach to test the hypothesis with 160 students of the Faculty of Economics University of Bung Hatta as a sample. We used non-probability sampling particularly purposive sampling method, which is required a specific criteria (Cooper and Schindler, 2011). The specified criteria is a student of economic faculty have attended courses in entrepreneurship.

We used validity and reliability tests to test research instrument. Validity test using confirmatory factor analysis (CFA) and reliability test using Cronbach's Alpha. Perceived entrepreneurial intention defined as an individual ambition or intention to demonstrate the behavior of a self-employment (Davidson, 1995) with a six-item scale. Perceived educational support is defined as the degree of where someone is intending to start a business based on the perception of education support (Hotel et al.,2008) witha six-item scale. Self confidence is a necessary entrepreneurial and it is related to other psychological characteristics, such as an internal locus of control, tend to take risk and tolerance of ambiguity Ho and Koh (1992) with three-item scale. Further, we used Hierarchical Regression Analysis (HRA) to analyze data with analytic consideration for mediation method (Baron and Kenny, 1982).

\section{RESULT AND DISCUSSION}

\subsection{Respondents Profile}

We used a questionnaire to collect data, in total there are 182 Muslims respondents. We eliminated 22 unusable responses and verified 160 valid questionnaire. Table 2 show the description of respondents i.e. type dominated by sex male (57.5\%), age range 21-23 years 
(84.4\%), plan a career in BUMN/BUMD (36.9\%), students who do not have a business while in College (76.9\%), entrepreneurship intention (36.3\%), attend in entrepreneurship courses (86.9\%).

Table 1

Profile Characteristics of Respondents $(n=160)$

\begin{tabular}{|c|c|c|c|c|c|}
\hline Variables & Frequency & $\%$ & Variables & Frequency & $\%$ \\
\hline Gender & & & Age & & \\
\hline Female & 68 & 42,5 & 18 - 20years & 22 & 13,8 \\
\hline \multirow[t]{3}{*}{ Male } & 92 & 57,5 & $21-23$ years & 135 & 84,4 \\
\hline & & & $>23$ years & 3 & 1,9 \\
\hline & 160 & 100 & & 160 & 100 \\
\hline Career Plan & & & Running Business while in & & \\
\hline Entrepreneur & 57 & 35,6 & College & 37 & 23,1 \\
\hline Civil servant & 15 & 9,4 & Yes & 123 & 76,9 \\
\hline BUMN/BUMD & 59 & 36,9 & No & & \\
\hline Private employee & 21 & 13,1 & & & \\
\hline \multirow{2}{*}{$\begin{array}{l}\text { Continue the family } \\
\text { business }\end{array}$} & 4 & 2,5 & & & \\
\hline & 160 & 100 & & 160 & 100 \\
\hline Entreprenuer & & & After College & & \\
\hline Intention & & & Entrepreneurship & & \\
\hline Yes & 66 & 36,3 & Entrepreneurial Intention & & \\
\hline \multirow[t]{3}{*}{ No } & 4 & 2,2 & Yes & 139 & 86,9 \\
\hline & & & No & 21 & 13,1 \\
\hline & 160 & 100 & 160 & 100 & 160 \\
\hline
\end{tabular}

Source: Data is processed (2018)

\subsection{The Results of The Testing Instrument Research}

First, we test the research instrument. It's aim to ensure item measurements is valid. Validity test using a Confirmatory Factor Analysis (CFA). Method of Kayser-Meyer-Olkin Measure of Sampling Adequacy and Bartlett's Test of Sphericity is used to evaluate the strength of linear association between items in the matrix of correlations. Score Kayser-Meyer-Olkin Measure of Sampling Adequacy $>0.50$ is considered acceptable and it indicates the factor analysis allowed. Score of Kayser-Meyer-Olkin Measure of Sampling Adequacy $=0.868$ (Bartlett's Test of Sphericity approx.: Chi-Square $=906.802, \mathrm{df}=66 \mathrm{Sig}$. at p. $<0.05$ ) for the model of research (see Table 2), which involves items that measure variables Perceived entrepreneurial intention, Perceived educational support, and Self-confidence. Further, overall 
total 12 items have shown is the value of the loading factor $>0.4$ (see Table 3 ). These result indicate that this measurement are valid.

Table 2

Score Kayser-Meyer-Olkin

KMO and Bartlett's Test

\begin{tabular}{|c|c|c|}
\hline \multicolumn{2}{|c|}{$\begin{array}{l}\text { Kaiser-Meyer-Olkin Measure of Sampling } \\
\text { Adequacy. }\end{array}$} & ,868 \\
\hline $\begin{array}{l}\text { Bartlett's Test of } \\
\text { Sphericity }\end{array}$ & $\begin{array}{l}\text { Approx. Chi-Square } \\
\text { df } \\
\text { Sig. }\end{array}$ & $\begin{array}{r}906,802 \\
66 \\
, 000\end{array}$ \\
\hline
\end{tabular}

Source: Data is processed (2018)

Table 3

Validity Test

\begin{tabular}{cccc}
\hline \multicolumn{4}{c}{ Rotated Component Matrix } \\
\hline \multirow{2}{*}{ Items } & \multicolumn{3}{c}{ Component } \\
\cline { 2 - 4 } & $\mathbf{1}$ & $\mathbf{2}$ & $\mathbf{3}$ \\
\hline EI1 &, 764 & & \\
EI2 &, 536 & & \\
EI3 &, 812 & \\
EI4 &, 589 & \\
EI5 &, 587 & \\
EI6 &, 545 & & \\
ES1 & & & \\
ES2 & & & \\
ES3 & & & \\
SC1 & &, 589 & \\
SC2 & &, 617 & \\
SC3 & &, 603 & \\
\hline
\end{tabular}

Source: Data is processed (2018)

To test reliability of this measurement, we used the cronbach's alpha coefficient. Table 4 shows all variables have a greater Cronbach's Alpha coefficient $>0.7$.

Table 4

Reliability

\begin{tabular}{lcc}
\hline \multicolumn{1}{c}{ Variables } & Item & $\begin{array}{c}\text { Cronbach's } \\
\text { Alpha }\end{array}$ \\
\hline $\begin{array}{l}\text { Perceived } \\
\text { entrepreneur intention }\end{array}$ & 6 &, 773 \\
\hline
\end{tabular}


Andalas Management Review, Vol. 3 No. 1, 2019

\begin{tabular}{llc}
\hline $\begin{array}{l}\text { Perceived educational } \\
\text { support }\end{array}$ & 3 &, 867 \\
\hline Self-confidence & 3 &, 855 \\
\hline
\end{tabular}

Source: Data is processed (2018)

\subsection{The Results of Hypothesis Testing}

The results of hypothesis testing is shown on table 4 and table 5 . Table 4 shows perceived educational support has a positive effect on Perceived entrepreneurial intention $(\beta=0.429$, $\mathrm{p}$ value $<0.000)$. In other word, perceived educational support has a positive effect on Perceived entrepreneurial intention at students of the Faculty of Economics at Bung Hatta University (H1 supported).

Table 5

Regression Testing

\begin{tabular}{llcccc}
\hline \multicolumn{1}{c}{ Hypotesis } & $\begin{array}{c}\text { Standardized } \\
\text { Beta } \\
\text { Coefficients }\end{array}$ & Sig. & $\begin{array}{c}\text { Adjusted } \\
\mathbf{R}^{2}\end{array}$ & $\mathbf{F}$ \\
\hline $\mathrm{H}_{1}$ & $\begin{array}{l}\text { Perceived educational support } \rightarrow \\
\text { Perceived entrepreneur intention }\end{array}$ & 0,429 & 0,000 & $35,614^{*}$ & 0,429 \\
\hline $\mathrm{H}_{2}$ & $\begin{array}{l}\text { Perceived educational } \\
\text { support } \rightarrow \text { Self-confidence }\end{array}$ & 0,594 & 0,000 & $86,051^{*}$ & 0,594 \\
\hline $\mathrm{H}_{3}$ & $\begin{array}{l}\text { Self-confidence } \rightarrow \text { Perceived } \\
\text { entrepreneur intention }\end{array}$ & 0,667 & 0,000 & $126,410^{*}$ & 0,667 \\
\hline
\end{tabular}

Note: *Significant at $p<0,01$

Source: Data is processed (2018)

Further, perceived educational support has a positive effect on self-confidence $(\beta=0.594$, $\mathrm{p}$-value < 0.000). It means the perceived educational support raises students self-confidence (H2-supported). self-confidence has a positive effect on perceived entrepreneur intention $(\beta=$ 0.667, p-value < 0.000). This finding supports our argument that self-confidence has a positive effect on perceived entrepreneur intention (H3 supported). 
Table 6

Mediation Testing

\begin{tabular}{|c|c|c|c|c|}
\hline Hypothesis & $B$ & Sig. & $\mathbf{F}$ & Result \\
\hline Steps 1 & & & & \\
\hline $\begin{array}{l}\text { Perceived educational support } \rightarrow \text { Perceived } \\
\text { entrepreneur intention }\end{array}$ & 0,429 & 0,000 & $35,614^{*}$ & \\
\hline $\begin{array}{l}\text { Steps } 2 \\
\text { Perceived educational support } \rightarrow \text { Self-confidence }\end{array}$ & 0,594 & 0,000 & $86,051^{*}$ & \\
\hline Steps 3 & & & & \\
\hline $\begin{array}{l}\text { Self-confidence } \rightarrow \text { Perceived entrepreneur } \\
\text { intention }\end{array}$ & 0,667 & 0,000 & $126,410^{*}$ & \\
\hline Steps 4 & & & & \\
\hline Perceived educational support & 0,051 & 0,491 & 35,615 & \\
\hline $\begin{array}{l}\text { Self-confidence } \rightarrow \text { Perceived entrepreneur } \\
\text { intention }\end{array}$ & 0,636 & 0,000 & 63,235 & \\
\hline $\begin{array}{l}\text { Result } \\
\text { Perceived educational support } \rightarrow \text { Self-confidence } \\
\rightarrow \text { Perceived entrepreneur intention }\end{array}$ & & & & $\begin{array}{c}\text { Full } \\
\text { mediation }\end{array}$ \\
\hline
\end{tabular}

To test a mediation effect from self-confidence on relationship between Perceived educational support and Perceived entrepreneur intention, we used mediation method was developed by Baron and Kenny (1986). They required several assumptions that have to be met are the following:

1) The relationship between the independent variable $(X)$ with the mediator variable $(M)$, significantly.

2) The relationship between the mediator variable $(\mathrm{M})$ and the dependent variable $(\mathrm{Y})$, significant.

3) The relationship between the independent variable $(X)$ and the dependent variable $(Y)$, significant.

4) The relationship between the independent variable $(X)$ and the dependent variable $(Y)$ and the relationship between the mediator variable $(\mathrm{M})$ and the dependent variable $(\mathrm{Y})$ shows the influence of the mediating. Full mediation when $X$ with $Y$, insignificant and $M$ with $Y$, significant. No mediation when $X$ with $Y$, significant and $M$ with $Y$, not significant. Partial mediation when $X$ with $Y$, significant and $M$ with $Y$, significant. 
Based on Baron and Kenny's assumption (1986), we find a mediation effect from self confidence on the relationship between Perceived educational support on Perceived entrepreneurial intention. It means Self-confidence plays a role as a mediator variabel that influence relationship between perceived educational support on Perceived entrepreneur intention. Based in this result, we can conclude that $\mathrm{H} 4$ is supported.

\section{DISCUSSION AND IMPLICATION}

This research purposes to understand the phenomenon of perceived educational support by tracing the influence of perceived educational support on Self-confidence and Perceived entrepreneurial intention by students Faculty of economics at Bung Hatta University. In General, the results shows a perceived educational support has a positive effect on selfconfidence and perceived entrepreneurial intention.

This study also confirm a positive effect of perceived educational support toward entrepreneurship intention. Students wih high level of perceived educational support are expected to use his knowledge to become an entrepreneur. Therefore, the perceived educational support plays an important role to create and develop an individual entrepreneurship intention.

Further, we also test self-confidence as mediating variable between the perceived educational support and perceived entrepreneur intention. The result shows that selfconfidence fully mediates relationship between the perceived educational support and perceived entrepreneur intention. When individual had a good level of knowledge about entrepreneurship, it will add a confidence level to become an entrepreneur. 
Andalas Management Review, Vol. 3 No. 1, 2019

\section{REFERENCES}

Adhitama, P.P., (2014), Faktor-faktor yang Mempengaruhi Minat Berwirausaha (Studi Kasus Mahasiswa Fakultas Ekonomika dan Bisnis UNDIP, Semarang), Skripsi, Fakultas Ekonomi UNDIP, Semarang.

Alma, Buchari, (2013), Manajemen Pemasaran dan Pemasaran Jasa, Alfabeta, Bandung.

Baron, R. M., \& Kenny, D. A. (1986). "The Moderator-Mediator Variable Distinction in Social Psychological Research: Conceptual, Strategic, and Statistical Considerations", Journal of Personality and Social Psychology, Vol. 51, pp. 1173-1182.

Bernstein, A. Crayannis, E. (2012). “Exploring the Value Proposition of the Undergraduate Entrepreneurship Major and Elective Based on Student Self-Efficacy and Outcome Expectations", Journal of the Knowledge Economy.

Blau. P \& Duncan. O (1967). The American Occupational Structure, John Wiley \& Sons, New York.

Cooper, D. R., \& Schindler, P. S., (2011), Business Research Methods 11 ed. McGraw-Hill International Edition, New Jersey.

Davidsson, P., (1995). Determinants of Entrepreneurial Intentions, Rent IX Workshop, Piacenza, Italy.

Farzier \& Niehm, (2008). An Assessment of the Entrepreneurial Intentions of College Students Majoring in Family and Consumer Sciences.

Gorman MA, et al., (1997) The Crystal Structure of the Human DNA Repair Endonuclease HAP1 Suggests the Recognition Of Extra-Helical Deoxyribose At DNA Abasic Sites. EMBO J, Vol. 16, No. 21, pp. 6548-58.

Hisrich. R \& Peters, M. (2002). Entrepreneurship. McGraw-Hill

Hair, J., Hult, G., Ringle, C., \& Sarstedt, M. (2014).A Primer on Partial Least Square Structural Equation Modelling (PLS-SEM). CA: Sage.

Ho, T. S. and Koh, H. C. (1992), "Differences in Psychological Characteristics Betweenentrepreneurially Inclined and Non-Entrepreneurially Inclined Accountinggraduates in Singapore", Entrepreneurship, Innovation and Change: An InternationalJournal, Vol. 1, pp. 243-54.

Kram, E.K, (1983). "Phases of the mentor relationship." The Academy of Management Journal, Vol. 26, No. 4, pp. 608-625

Krueger, N., \& Brazeal, D.V. (1994). “Entrepreneurial Potential and Potential Entrepreneurs." Entrepreneurship Theory and Practice Journal Vol. 5, pp. 91-104.

Kourilsky, M.L. \& Walstad, W.B. (1998). “Entrepre-neurship and Female Youth: Knowledge, Attitudes, Gender Differences and Educational Practices." Journal of Business Venturing, Vol. 1, No. 1, pp. 77-88.

Lauster, P., (2003). Tes Kepribadian (alih bahasa: D.H. Gulo). Jakarta: PT. Bumi Aksara.

Marpiere, A., (1982). Psikologi Remaja. Surabaya: Usaha Nasional 
Meredith, Geoffrey G, (2002). Kewirausahaan: Teori dan Praktek, PPM, Jakarta.

Muhadjir. N. (1992). Perencanaan dan Kebijakan Pengembangan Sumber Daya Manusia. Rake Sarasin

Nabi, G, Holden, R. Walmsley, A (2006). Graduate career making and business start up: a literature review. Emerald Group Publishing Limited.

Rogoff G \& Heck. R.K.Z (2003). "Evolving research in entrepreneurship and family business: Recognizing family as the oxygen that feeds the fire of entrepreneurship." Journal of Business Venturing, Vol. 18, No. 5, pp. 559-566.

Sagie, A., \& Elizur, D. (1999). "Achievement motive and entrepreneurial orientation: A structural analysis." Journal of Organizational Behavior, Vol. 20, No. 3, pp. 375-387.

Sarwoko, E. (2011). “Kajian empiris entrepreneur intention mahasiswa." Jurnal ekonomi bisnis Vol. 16 No. 2, pp. 126-135

Schunk, D. H. (2012). Learning Theories, an Educational Perspective. Ed. 6. Boston, MA: Pearson Education Inc.

Shapero, A. and Sokol, L. (1982) The social dimensions of entrepreneurship. In C.Kent, D. Sexton and K. Vesper, (Eds.), Encyclopaedia of entrepreneurship, pp. 72-90.

Supriyatno, B., (2017). Pengaruh Kepercayaan Diri Dan Motivasi Terhadap Minat Berwirausaha Mahasiswa Program Studi Pendidikan Ekonomi STKIP PGRI Ngawi. Jurnal Media Prestasi.

Suryana, (2003). Kewirausahaan Pedoman Praktis: Kiat dan Proses Menuju Sukses, Edisi Ketiga. Jakarta: Salemba.

Suryana, (2006). Kewirausahaan Pedoman Praktis: Kiat dan Proses Menuju Sukses, Edisi Ketiga. Jakarta: Salemba.

Sutanto, A. 2002. Kewiraswastaan. Malang : Ghalia Indonesia

Tarmudji. T., (2006). Prinsip-prinsip Kewirausahaan. Yogyakarta:Liberti.

Tjahjono, H.K. \& Ardi, H., (2008). "Kajian Niat Mahasiswa Manajemen Universitas Muhammadiyah Yogyakarta untuk Menjadi Wirausaha." Jurnal Manajemen dan Bisnis, Vol. 16 No. 1, pp. 46-63.

Turker, D.and Selcuk,S. (2008) in Turkey, "Which factors affect entrepreneurial intention of university students?", in Turkey, Journal of European Industrial Training Vol. 33 No. 2, 2009, pp. 142-159.

Wu. S \& Wu. L., (1998). "The Impact of Higher Education on Entrepreneurial Intentions of University Students in China." Journal of Small Business and Enterprise Development, Vol. 15 No. 4, pp. 752.

Zimmerer, W.T., (2002). Essentials of Entrepreneurship and Small Business Management.Third Edition. New york: Prentice-Hall. 